Open Access

\title{
The radical market-oriented policies of the Alternative for Germany (AfD) and support from non-beneficiary groups - discrepancies between the party's policies and its supporters
}

Juho Kim(D)

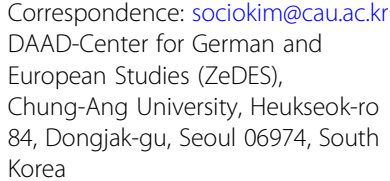

Correspondence: sociokim@cau.ac.kr DAAD-Center for German and European Studies (ZeDES),

Chung-Ang University, Heukseok-ro 84, Dongjak-gu, Seoul 06974, South Korea

\begin{abstract}
This paper examines the strong support for Alternative für Deutschland (AfD) from lower socio-economic groups like blue collar workers and the unemployed in Germany, who would be most economically weakened by the radical market-oriented policies of this party. The AfD has achieved remarkable electoral successes within a short period of time, with the main basis of the support it receives coming from the above-mentioned demographic groups. These are not the dominant segment or the majority of all the supporters of the AfD, but they provide a considerable proportion of the party's votes and are the groups which display the highest approval ratings for the AfD. Their support is quite surprising, given the fact that the economic, labor, welfare and tax policies of the party are very market-oriented. In this light, this paper focuses on the major factions (the economic liberal and the national conservative) and main agenda items (opposition to the euro and antipathy to immigration and refugees) of the AfD, and demonstrates the discrepancies between the party's policy goals and the circumstances and needs of the core groups which support the party. The two internal party factions prioritize different agendas, though they are both fundamentally opposed to the existing euro system and the influx of immigrants and refugees to Germany. The party's radical market-oriented policies were devised under the influence of the eurosceptic economic liberalism which played a leading role in the party's foundation and in its initial phase. However, even in the early period when it drew most attention as an anti-euro party, the AfD owed its electoral successes to its anti-immigration and anti-refugee stance rather than to its antieuro position. The former issues were more emphasized by the national conservatives within the party after they won the ideological struggle with the economic liberals. The anti-immigrant and anti-refugee policies first appealed to blue collar workers and the unemployed. In addition, their support was mobilized effectively by the election strategy of the AfD, which campaigned mainly on an anti-immigration and anti-refugee platform, and obscured or de-emphasized the radical market-oriented policies of the party.
\end{abstract}

Keywords: Right-wing populism, Market radicalism, Blue collar and unemployed voters, Economic liberal faction, National conservative faction, Anti-euro, Anti-immigration and anti-refugee 


\section{Introduction}

The presence of a right-wing populist party appears to have become the norm rather than the exception in contemporary European politics. The National Front of France, the representative right-wing populist party in Europe, made it to the second round of the 2017 presidential election, with Marine Le Pen as its party leader. The Freedom Party of Austria became the third largest party after the 2017 parliamentary election and has joined the country's coalition government. The Dutch Party for Freedom emerged as the largest opposition party in the House of Representatives, winning 13.1\% of votes in the 2017 general election. Others that are regarded as right-wing populist parties - the UK Independence Party, the Northern League of Italy, the Flemish Interest of Belgium, the Danish People's Party, the Progress Party of Norway, the Swedish Democrats, the Finns Party, the Law and Justice Party of Poland, and the Jobbik party of Hungary - are exerting great influence not only on the domestic politics of their respective countries but also on the European political landscape as a whole.

They share similar stances and characteristics, such as Euroscepticism, antimulticulturalism, anti-politics, dichotomous thinking, and proclivity for incitement and provocation (Judith 2016: 89-108). Upon closer examination, however, one will find considerable differences among these groups (Ibid. 131-153; Priester 2016). Their economic policies are especially intriguing. While some parties, such as the National Front of France, advocate for social state policies and trade protectionism, others such as the Freedom Party of Austria are underpinned by economic liberalism. The latter stands in opposition to European integration, but does not advocate for the raising of trade barriers to protect its domestic economy. Likewise, although the UK Independence Party claims to be in favor of economic liberalism, it played a decisive role in Brexit, which would isolate the UK from the European continent.

The Alternative for Germany (Alternative für Deutschland, AfD), which quickly maneuvered itself into mainstream institutional politics subsequent to its founding in 2013, is highly liberal in regard to the economy. Backed by adamant belief in the power of the free market, AfD has been a contender against "artificial" bailout measures for Eurozone countries in crisis and has projected extreme anti-interventionist views on its economic and social policies. In fact, the AfD is intent on partially abolishing parts of social insurance programs and is averse to the minimum wage system. It seeks to reform income tax to curb its progressive nature and abolish a fair number of taxes that promote income redistribution, such as property taxes and inheritance taxes. One of the particularly pressing questions that arise in light of these policies is why the AfD is receiving strong support from the groups that are least likely to benefit from such radical market-oriented policies. Ironically, the groups that stand to fare the worst in market competition and benefit the most from state intervention and support, such as blue collar workers and the unemployed, have laid the foundation for AfD's success.

How must one understand such discordance between the party's followers and its policies? Why does AfD promote radical market-oriented economic policies, and yet, have the main body of its supporters constituted by groups who would not benefit from such policies? This study will tackle these questions by examining AfD's developmental history and the differing forces that exist within the party.

This study will begin by analyzing the main supporting groups and policies endorsed by the AfD. The analysis will confirm that the party's radical market-oriented policies 
do not coincide with the interests of its main supporting groups, which are largely made up of blue collar workers and the unemployed, often with limited education. Subsequently, two major factions and two key agendas within the AfD will be discussed, providing clues toward understanding such discrepancies. The radical market-oriented nature of the party can be attributed to Eurosceptic economic liberals who founded and led the party during its nascent stage. On the other hand, the support from blue collar workers and the unemployed can only be understood in relation to the national conservatives' closed attitude toward immigrants and refugees. Although both forces share similar anti-Euro and anti-immigrant/refugee sentiments, their priorities differ. Lastly, the reason behind support of the blue collar workers and the unemployed for the AfD despite the party's unfavorable economic policies will be investigated in relation to the emergence of anti-immigration and anti-refugee sentiments and AfD's shrewd election strategies.

\section{Supporter demographics and policies}

\section{Emergence of blue collar workers and the unemployed as key supporters}

The AfD, which appeared in the aftermath of the Euro Crisis at the end of 2000s, did not take long to establish itself as one of the central axes of German institutional politics. In 2013, the year of its foundation, the AfD narrowly lost its chance at entering the parliament, earning $4.7 \%$ and $4.1 \%$ of the votes in Federal and Hessian state elections, respectively, which fell short of the $5 \%$ minimum criterion. Nevertheless, the party promptly took off in the following year (see Fig. 1), beginning with the European Parliament election. It won $7.1 \%$ of votes in the election held in May 2014 and secured a total of seven parliament seats. Soon after, the party won about $10 \%$ of votes in state parliament elections in three states of former East Germany (Sachsen, Brandenburg, and Thuringia), securing its entry into the state parliament. Although the number of votes was relatively

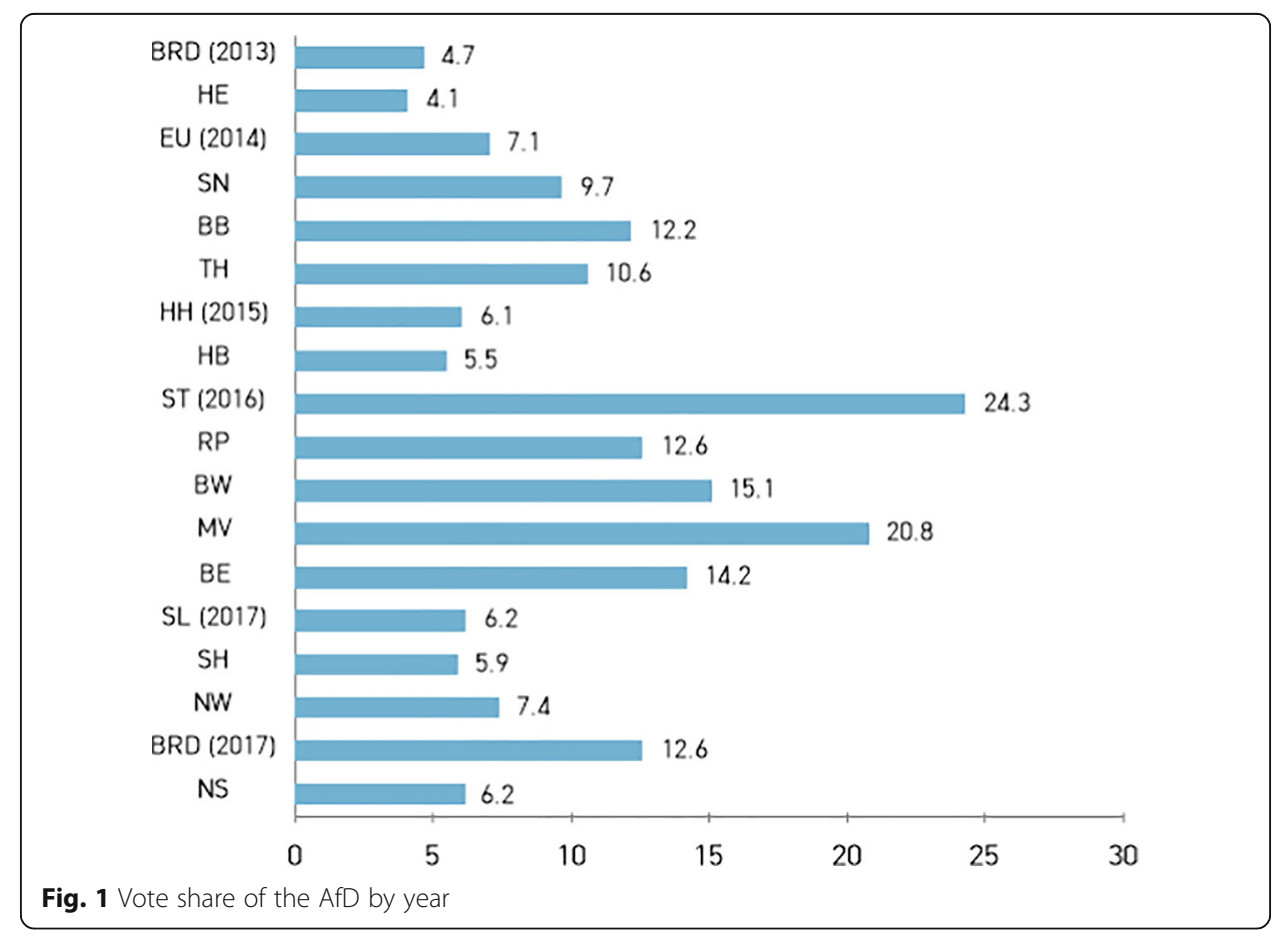


low, it won seats in two northern state parliaments (Hamburg and Bremen) in 2015, expanding its influence over former West Germany as well. Throughout 2016 and 2017, the AfD won nine state elections, thereby achieving its incredible feat of entering all of the state parliaments since 2014. The year 2016 was a particularly astonishing year. With the refugee crisis looming as a key issue, the party won an average of $17.4 \%$ of votes across five elections, more than double the average it had won before. Those percentages were surpassed in Sachsen-Anhalt and Mecklenburg-Vorpommern, where the party won 24.3\% and $20.8 \%$ of the votes, respectively, making it the main opposition party in the national parliament despite its relatively recent emergence. Eventually, it became the third party in the Federal Parliament, winning 12.6\% of the votes in the 2017 Federal Parliament election. The AfD has thus broken in from the periphery of German politics and is becoming one of the central forces in its institutional political landscape.

There have been conflicting research findings regarding which social groups support the AfD. Some studies identify main supporters of the AfD in well educated, high income groups, while other studies report the opposite, claiming that the majority of low income voters with limited education support the party. A short report published by the Cologne Institute for Economic Research in 2016 finds evidence in support of the former argument (Bergmann et al. 2016). This institute analyzed political party preferences prior to the European Parliament election in 2014 and found that a considerable number of AfD supporters earn a higher than average income. It reported that about $34 \%$ of the respondents who favored the AfD were in the top $20 \%$ income group, while only $15 \%$ of the respondents were in the bottom $20 \%$ (see Fig. 2). This report is rather inconsistent with the AfD's self-evaluated claim of being a "petite bourgeoisie party" and the public's general perception toward the AfD. Such evaluations and perceptions seem more fitting for the Social Democratic Party of Germany (Sozialdemokratische Partei Deutschlands, SPD) and the Right Party (Die Rechte), the far-right minority parties, and the Left Party (Die Linke) among the Federal Parliament parties.

It is clear that the AfD has support of the high-income earners more so than that of the low-income earners when only the results discussed above are considered. It appears to be somewhat hasty, however, to say that the AfD is a political party for "only" high income earners. One should not forget that a considerable portion of AfD

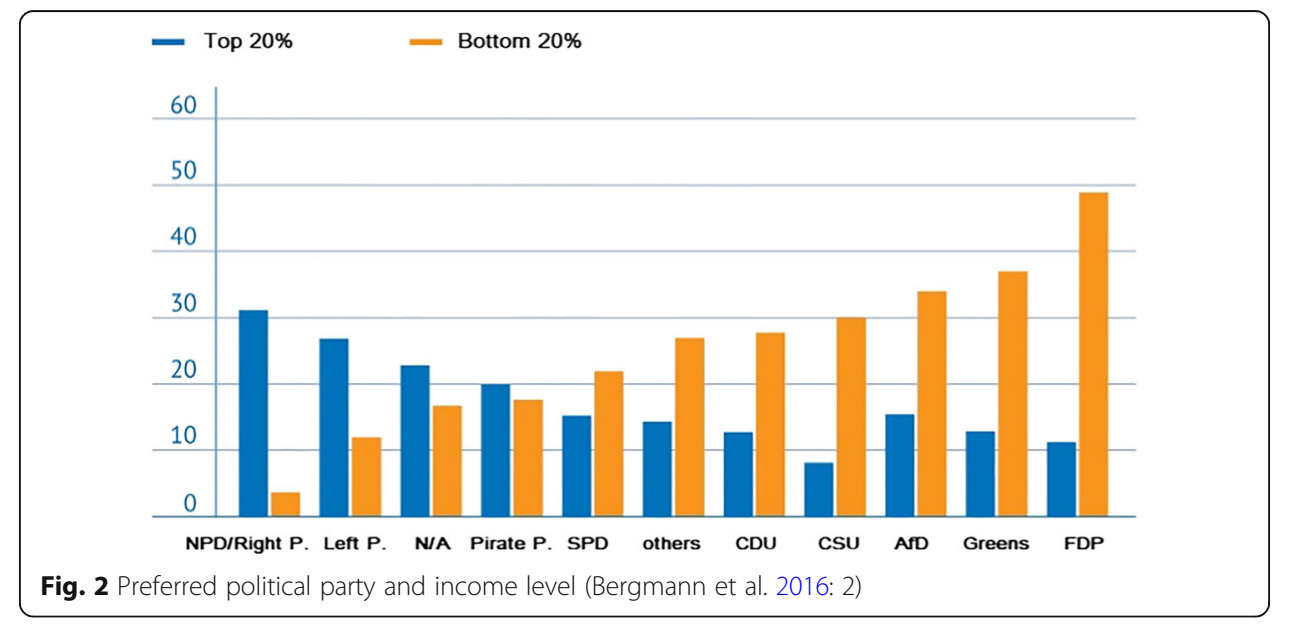


supporters belong to the bottom $20 \%$ of the wage-earning spectrum. Excluding left-leaning and minority parties, the AfD, along with the center-left SDP, have the highest proportion of people in the bottom $20 \%$ income bracket as their total number of supporters. This suggests that the AfD has another support base on the opposite side of the income spectrum.

The psychosocial survey of the University of Leipzig research team offers insight into this phenomenon. The survey has been conducted biennially since the early 2000s. Because it traces the changes in political constituency over time, it can complement the survey from the Cologne Institute for Economic Research, which only addresses the beginning of 2014 and the early stage of AfD. In fact, the survey's recent findings show a major change in the AfD's constituency (Brähler and Decker 2014; Brähler et al. 2016). What is most interesting is that there was a great surge of low income earners with limited education in two years following 2014. Figure 3 shows the proportion of supporters of each political party whose monthly household income is 1000 euros or less. Only 3.9\% of the AfD's supporters belonged to that category in 2014, which was the second lowest after that of the Free Democratic Party (Freie Demokratische Partei, FDP).

The findings of the 2016 survey, however, were quite different from those of 2014 . The proportion of the supporters of the AfD with household income of 1250 euros or less reached 18.7\% (see Fig. 4), a 15\% increase from 2014. This proportion is the second highest following that of the Left Party, which is regarded as the champion for minority groups. Of course, the proportion of the marginalized among supporters increased for all parties due to the limit of monthly household income being raised to 1250 euros, but no other party had as remarkable a leap as the AfD.

The introduction of new supporters into the AfD constituency is further highlighted by the survey on political party preferences and education level. Figure 5 shows the proportion of supporters with Abitur. Unlike other parties that showed minute changes, the percentage of those who made Abitur dropped by $5 \%$, from $21.2 \%$ in 2014 to $16.2 \%$ in 2016 in the case of the AfD. This percentage is the lowest among the six parties surveyed in 2016 - lower than not only the Greens, the Left Party, and the FDP, which have much higher Abitur pass rates, but also the SPD and the Christian Democratic Union (Christlich Demokratische Union Deutschlands, CDU)/Christian Social Union

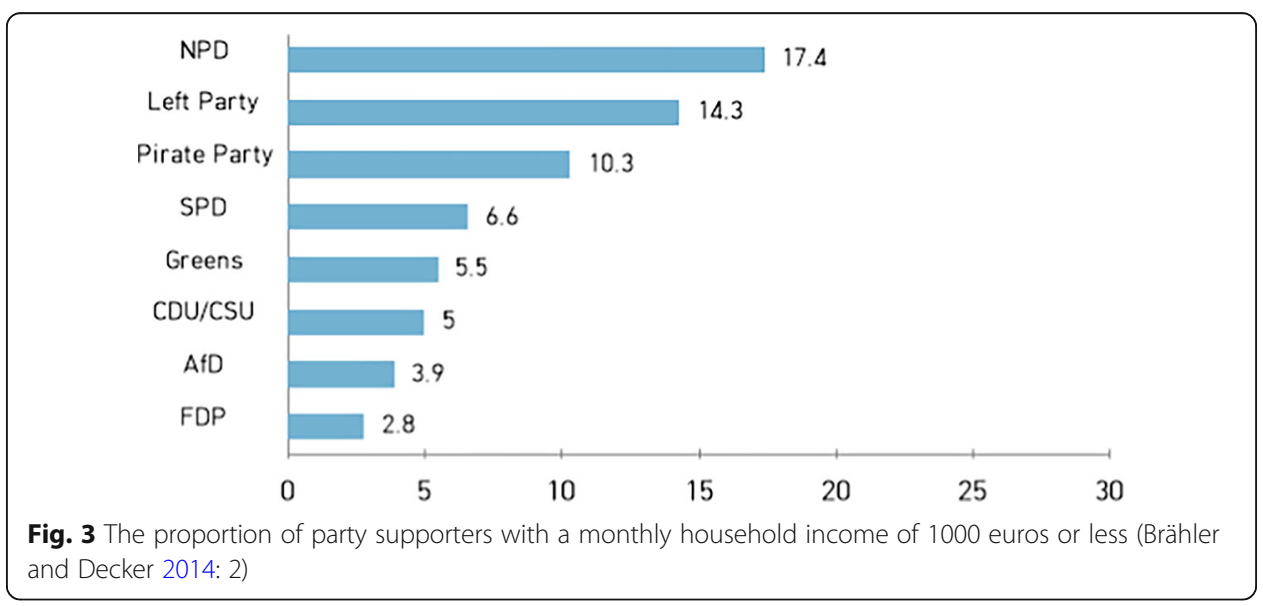




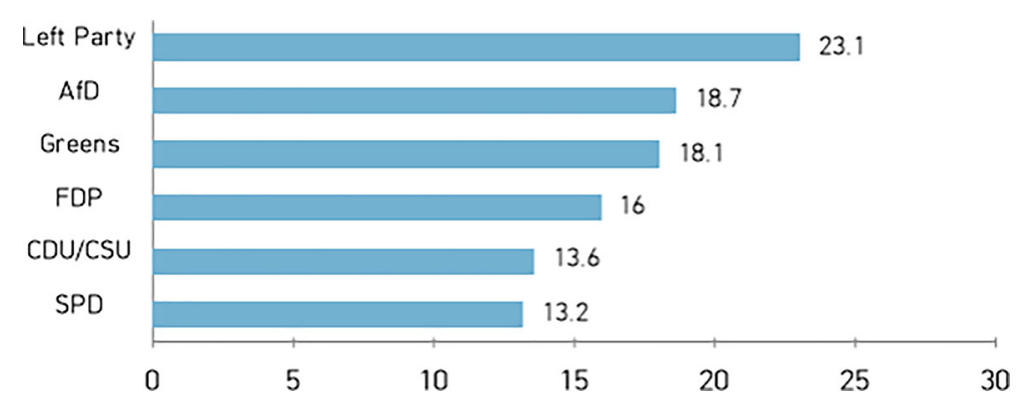

Fig. 4 The proportion of supporters with monthly household incomes of 1250 euros or less per party (Brähler et al. 2016: 73)

(Christlich-Soziale Union in Bayern, CSU), which in 2014 had lower pass rates than the AfD by $2.6 \%$, and $4.8 \%$, respectively.

The analysis of State Parliament election results by Infratest dimap also supports the University of Leipzig's study. A comparison of the total vote share per party to the vote share per livelihood pattern shows a mass turnaround of low income earners with low education level toward the AfD between 2014 and 2016. Previously, the largest vote share from blue collar workers and the unemployed won by the AfD was mid-10\%, but it reached mid-30\% in 2016 (Infratest dimap 2013-2017). This made AfD the party with the largest number of votes from blue collar workers and the unemployed in all five states that hosted state parliament elections that year, except for Rhineland-Palatinate. It outnumbers the second-place party by a large margin as well. In the case of Sachsen-Anhalt state parliament election where the AfD had its biggest victory, the support of blue collar workers and the unemployed was more than $1 / 3$ of the total, rating $35 \%$ and $36 \%$, respectively (see Table 1). It is 15\% (CDU) and 20\% (the Left Party) higher compared to the second place. If one takes only the 2016 state parliament elections into account, the AfD is more representative of blue collar workers and the unemployed than the SPD and the Left Party. Indeed, the AfD won a larger vote share among the other livelihood types (white-collar workers, self-employed people, and pensioners) than the previous parliament elections. The vote shares among those livelihood types, however, increased rather insignificantly and were almost always lower than the total vote share of the AfD (Infratest dimap 2013-2017). Furthermore, the party never won larger vote share than any of the other

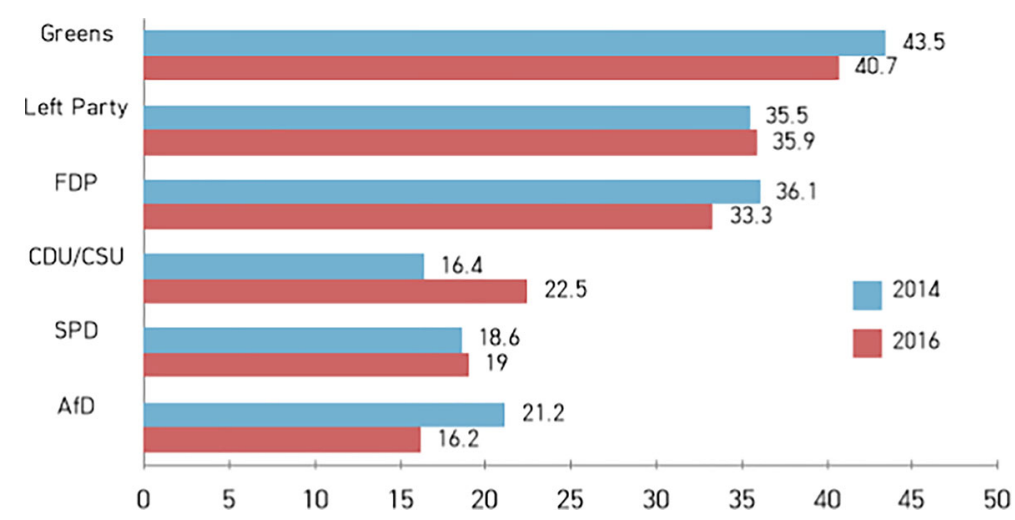

Fig. 5 Abitur pass rate of the supporters per party (Brähler and Decker 2014: 4; Brähler et al. 2016: 70) 
Table 1 The approval rating for the AfD among blue collar workers and the unemployed in the 2016 State Parliament elections (Source: Infratest dimap 2013-2017)

\begin{tabular}{llllll}
\hline State & \multicolumn{2}{l}{ Blue Collar Workers } & & Unemployed & \\
\cline { 2 - 3 } & $\begin{array}{l}\text { Approval rating } \\
\text { (ranking) }\end{array}$ & $\begin{array}{l}\text { Difference between } \\
\text { 1st and 2nd place }\end{array}$ & & $\begin{array}{l}\text { Approval rating } \\
\text { (ranking) }\end{array}$ & $\begin{array}{l}\text { Difference between } \\
\text { 1st and 2nd place }\end{array}$ \\
\hline Sachsen-Anhalt & $35 \%(1)$ & $+15 \%$ & $36 \%(1)$ & $+20 \%$ \\
Rhineland-Palatinate & $23 \%(2)$ & $-14 \%$ & $25 \%(2)$ & $-5 \%$ \\
Baden-Württemberg & $30 \%(1)$ & $+8 \%$ & $32 \%(1)$ & $+12 \%$ \\
Mecklenburg-Vorpommern & $33 \%(1)$ & $+6 \%$ & $29 \%(1)$ & $+7 \%$ \\
Berlin & $28 \%(1)$ & $+11 \%$ & $22 \%(1)$ & $+5 \%$ \\
\hline
\end{tabular}

parties if one excludes the self-employed people from the Mecklenburg-Vorpommern state parliament election (Ibid.). The results of the 2017 Federal Parliamentary elections were not much different. The approval rating for the AfD among blue collar workers was $21 \%$, which was lower than that of the CDU/CSU (25\%) and of the SPD (24\%), but it was $15 \%$ higher than the result of the 2013 Federal Parliament election (Infratest dimap 2013, 2017). It is contrasting to the drop of $10 \%$ and $3 \%$ for the CDU/CSU and the SPD, respectively. Similar results were seen in the approval rating of the unemployed. While the AfD won 22\%, which is a $19 \%$ increase from four years ago, the CDU/CSU dropped by $4 \%$ to win $20 \%$ and the SPD dropped by 3\% to win 23\% (Ibid.). The results of the State and the Federal Parliament elections clearly attest to which social groups have driven the resounding success of the AfD - blue collar workers and the unemployed with low income and education.

Surely, the AfD still cannot be considered the party for blue collar workers and the unemployed. Just because the majority of a particular social group supports a political party does not necessarily mean they represent the party's majority base. According to a study by Niedermayer and Hofrichter (2016), the proportion of unemployed among all supporters of the AfD and the proportion of blue collar workers among its supporters with livelihood activities during the first quarter of 2016 were only 3\% and $26 \%$, respectively. ${ }^{1}$ However, the rapid surge of blue collar workers and the unemployed as the main supporters of the AfD cannot be denied. This phenomenon is also observed in a study by Niedermayer and Hofrichter. The approval rating for the AfD among blue collar workers showed a rapid increase, from 4\% in the 4th quarter of 2013 to $18 \%$ in the 1st quarter of 2016 , and approval rating in the case of the unemployed also increased considerably, from $7 \%$ to $12 \%$ during the same period (Ibid. 273). Increase in approval rating among blue collar workers was steeper than that of any other social group - its rate more than quadrupled (4.5 times) - and consequently, the proportion of blue collar workers among the entire supporters show rapid expansion. The $26 \%$ rating recorded in the 1st quarter of 2016 is a result of a $6 \%$ increase in only about two years subsequent to the 4th quarter of 2013 (Ibid. 272). Considering that other occupational groups did not show much change in their ratings or even dropped in their rating during the same period, even though the approval rating for the AfD increased for each group, this is a significant and meaningful change. In sum, although social groups such as blue collar workers and the unemployed are not the absolute majority among the supporters of the AfD, the approval rating for the AfD within those groups is increasing faster than for any other group, and their prominence as main supporting groups of the AfD is also growing. 


\section{Radical market-oriented economic policies}

This section briefly examines the AfD's general approach to economy, labor policies, social insurance policies, and tax policies to show that its economic policies do not adequately represent the interests of blue collar workers and the unemployed, and are in fact against it. Three official policies announced by the AfD on a federal level - the 2013 Federal Parliament election manifesto, its basic doctrine, and the 2017 Federal Parliament election manifesto - will be used as baseline data (AfD 2013, 2016a, 2017). The party's basic doctrine, which was announced three years after its formation, will be studied in greater depth, because it is a concise and systematic summation of the policies and stances of the party that were expressed sporadically by individual politicians and states prior to the doctrine's culmination.

The AfD's policies are founded on firm and absolute trust in market and competition. The AfD claims to be oriented toward a social market economy (Soziale Marktwirtschaft) in its basic doctrine (AfD 2016a: 67), but it appears that of its two foundations, Ordoliberalism and social state (Sozialstaat), the former is emphasized over the latter. While it is true that the definition of social state varies depending on one's political alliance and can be interpreted to accommodate a variety of social situations, one cannot help but doubt the AfD's alignment with the social state, as it is clearly contradicted by the policies discussed below. Ordoliberalism, which emphasizes competition, seems to be the starting point of the party's position and policies in regard to the economy, as well as all other areas (Bebnowski and Förster 2014). In chapter 10, the first clause of its basic doctrine, "Free competition brings us wealth," the AfD describes the basic philosophy behind their economic policies as follows:

The best economic performance is produced in competitive market economy. ... the greater the competition, and smaller the state intervention, the more beneficial it is for everybody. This is because freedom to self-development and self-decision making, freedom to take private property as a means of goods and production, freedom to sign a contract under one's own liability for one's own interest and wealth, freedom of choice among many suppliers, products, services, or jobs, freedom to take advantage of opportunities that bring profits, and freedom to take responsibilities for potential failures are created by competition. ... except in a few cases - e.g., to stop monopolies and to prevent market failure - state interventions should be kept at minimum and computation should be made possible for domestic and foreign investors. This is the objective of a competition-oriented economy. (AfD 2016a: 67)

The economic policies central to the AfD - opposition to Eurozone bailout loan, lifting of trade barriers, deregulation and de-bureaucracy, reduction of government subsidies and limit on support period, and reduction of public domain - have been drawn from these doctrines, which are grounded in market liberalism, laissez-faire government, and anti-interventionism (AfD 2016a: 66-71; 2017: 52).

Labor policies were also prepared on the same ideological platform. The AfD announced official acceptance of a minimum wage, but its true intention has been clouded by comments from its key members, and there has been no practical evidence of its support in the form of policy change (Nocun 2016: 10-15). Bernd Lucke, who represented the party in its early stage, opposed the introduction of minimum wage promoted by the 
coalition between the CDU and the SPD, for the reason that it could harm national competitiveness. Frauke Petry, who was the co-representative of the party at that time, crudely criticized the minimum wage system at a press conference in April 2015, calling it "a way to kill jobs," "socialistic romanticism," and "neo-socialist ideology of the SPD" (Frankfurter Allgemeine Zeitung 2014). The AfD stipulated the maintenance of a minimum wage system in its basic doctrine for the first time in 2016, and reiterated it in its Federal Parliament election manifesto one year later. However, they only provided theoretical and abstract reasoning for why the system is needed, with no substantial content such as the amount of minimum wage that they would set (AfD 2016a: 35; 2017: 52). Policies related to temporary employment, such as dispatched work and subcontracts, were left in ambiguity for a long time. The party expressed clear opposition to related regulations before the 2014 European Parliament election, but did not reflect it in its basic doctrine due to conflicting views within the party (Nocun 2016: 16-18). The official position of the party was finally confirmed before the 2017 Federal Parliament election, and it calls for the ratio of dispatched and subcontract workers to be limited to $15 \%$, for dispatched workers to be converted to full-time employees after six months of employment, and for part-time labor contracts to be extended only once (AfD 2017: 52). These seem somewhat out of character, considering the basic position that the party has maintained so far.

The party's social insurance policy is based on radical market liberalism and a strict merit system. The employment insurance policy proposed by the party is as follows: unemployment benefit $\mathrm{I}$, which provides a certain percentage of the previously earned income for 12 months immediately after unemployment, will be linked to the unemployment insurance premium payment leading up to unemployment, and unemployment benefit II, which provides the social benefit necessary for sustenance of livelihood leading up to one's employment, will be reduced when there is supplementary income (AfD 2016a: 37; 2017: 58). The party's retirement plan is also rooted in the principle of differential insurance benefits that vary depending on one's degree of contribution (AfD 2017: 57). What requires attention is the proposal stipulating that reception of normal pension benefits is only possible after working for a minimum of 45 years. With the current legal age for receipt of pension benefits set at 65 to 67 years depending on the year of birth, this could drastically increase the age criterion. Oddly, there is no mention of occupational health and safety insurance or medical insurance stated in the official materials of the party except for an abstract statement on medical insurance in its 2013 party platform (AfD 2013: 3). What is even more surprising is that the actual position of the AfD on social insurance policy can be more "radical" than what is presented in the party platform and the manifestos. According to the draft of the basic doctrine leaked to the press, the AfD was planning on abolishing unemployment benefit I and occupational health and safety insurance entirely (Spiegel Online 2016). The party maintains that unemployment and industrial accidents are extremely personal matters, and that the employer should be held responsible for compensation without help from the state or the corporation. Indeed, in a survey of its own party members, $64.5 \%$ and $53.6 \%$ agreed with the abolition of unemployment benefit I and abolishment of occupational health and safety insurance, respectively (Nocun 2016: 19).

Tax policy can be summarized as an elimination of income redistribution. First, in the case of income tax, the party argues for the simplification of the tax system and an 
increase in basic tax exemption amount in the name of fair taxation (AfD 2016a: 74). As already stated in the Federal Parliament election manifesto of 2013 (AfD 2013: 3), it is derived from a model devised by a tax law scholar and former judge at the constitutional court, Paul Kirchhof, in 2003. Simplification of tax assessment brackets in which tax is exempt for annual income of ten thousand euros or less, 15-20\% taxation for income up to twenty thousand euros, and a flat tax rate of $25 \%$ for income greater than twenty thousand euros, and abolishment of all extraneous tax benefits are central to this model. If the model is introduced, a maximum of $20 \%$ income tax cut can be expected, and those in the high-income brackets will become the biggest beneficiaries. Those who belong in the middle- and low-income brackets will face greater economic burdens. Although they may benefit momentarily from the reduced tax due to overall reduction of income tax rate, their economic burden will be greater in the long run as tax revenues and social expenditure are reduced. The policies of the AfD on other taxes that are designed to bring about income redistribution are just as preposterously simple and radical. In its 2017 Federal Parliament election pledges, the party stated its aim of having the property and inheritance tax be completely abolished in the basic doctrine, business tax be on abolition hold in the basic doctrine, and real-estate tax and land acquisition tax be reduced (AfD 2016a: 75; 2017: 70). Analyzing the leaked draft of the basic doctrine, the actual party platform on these taxes appears to be near abolition (Spiegel Online 2016). There is no doubt that this series of tax policies is absolutely beneficial to the rich (Nocun 2016: $26-32)^{2}$

The radical nature of the AfD's economic policies is evident when juxtaposed with those of other political parties. As illustrated in Fig. 6, the AfD takes the rightmost position on the ideological spectrum, with economy on the abscissa (left $\rightarrow$ right) and social policies on the ordinate (right $\rightarrow$ left). Especially in regard to the economy, it shows a strong bias toward the right side of the scale, approaching the maximum value of 10. It is far ahead of the FDP, which is the most market-friendly among the existing parties. The AfD's radical nature as such has never been subdued, even after it entered

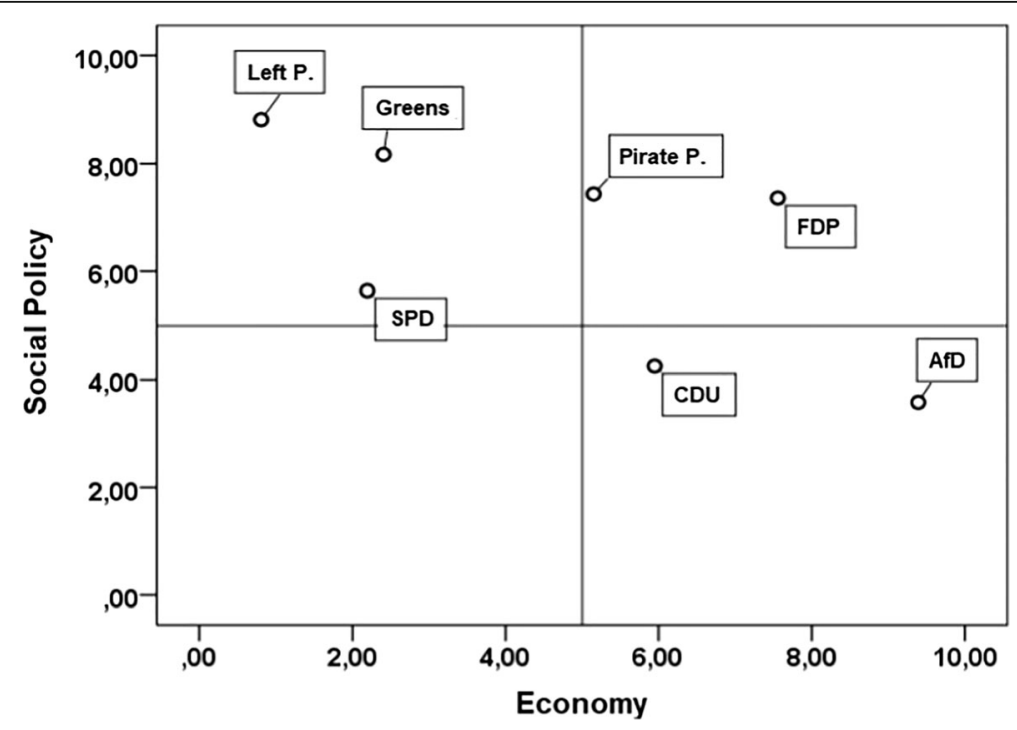

Fig. 6 Ideological positions of German political parties (Franzmann 2014: 120) 
the arena of institutional politics. On the contrary, it became more conservative in order to attract right-wing voters as $\mathrm{CDU}$ and other right-wing parties moved further to the left to target the neutral class, thereby freeing space on the right side of the spectrum for the AfD to take over (Infratest dimap 2015).

\section{Key forces and main agendas}

\section{Economic liberalism and anti-euro agenda}

The market radical economic policies of the AfD can be explained by its developmental history. It was established by critics of European Integration who advocated for economic liberalism. As discussed above, the AfD appeared in the aftermath of the Euro Crisis at the end of 2000s, but it can be traced back even further to the early 1990s, when the Maastricht Treaty was signed (Häusler and Roeser 2015: 28-41; Werner 2015: 19-33). With the signing of the treaty, a new kind of Euroscepticism emerged, which ultimately lead to the fruition of the AfD about 20 years later. The Maastricht Treaty opened up a new chapter of European integration, which began with the creation of the European Coal and Steel Community (ECSC) in 1952. The treaty represented a move beyond the existing alliance, which was limited in many ways to maintain peace and economic solidarity. The treaty called for the establishment of a unified political and monetary community and laid out the foundation for practical measures such as the establishment of the EU, the European Central Bank, and the single currency system. This attempt to develop and expand European integration, however, was met with intensification and expansion of Euroscepticism in many European countries. Many found dissatisfaction with restricted sovereignty and acceptance of multiculturalism, which were inevitable for advanced integration, and such sentiments gained considerable followings. One such trend was created by a group of right-wing economic liberals. Of course, not all economic liberals were against European Integration. One of the major driving forces of European Integration is economic liberalization, so naturally there were economic liberals supporting European Integration. Dieter Plehwe (2016) named this trend "transnational economic liberalism" and differentiated it from Eurosceptic economic liberalism that opposes European integration, which he named "right-wing liberalistic" or "national-liberalistic economic liberalism." The two forces are essentially identical in terms of being anti-statist, but they have different perspectives on the proper role of the state in order for capitalism to function smoothly. Advocates of Eurosceptic economic liberalism who acknowledge the inherent role of the state worried that the Maastricht Treaty would prevent the establishment and execution of stable economic policies at the state level by limiting national sovereignty, and interfere with the smooth operation of the market due to an increase in unfair political interventions upon the economy. These forces existed on the periphery of European politics for a while, began to distinguish themselves in the mid-2000s, then gradually made their way into Europe's mainstream institutional politics with the Eurozone crisis of 2008.

Germany was not an exception to this trend. After the Maastricht Treaty was signed, Euroscepticism spread among economists who were firmly rooted in liberal ideologies. Some used their specialty to criticize the plan for a European monetary community and expressed their skepticism about hasty European integration. For example, the anti-Maastricht Treaty declaration, which was signed by a total of 62 economics 
professors including Ohr and Schäfer (1992) in June 1992, listed the risks associated with the plan, such as an economic gap among member countries, the structural defects of monetary community, and the possible tarnishing of the economy by political agenda, and warned that the introduction of a single currency could trigger conflicts in Europe rather than encourage integration. A declaration of a similar nature was also announced in 1998, just before the introduction of the Euro. A total of 160 economics professors expressed their concerns about the flaws and hastiness of Euro introduction through a declaration (Kösters et al. 1998). The opposition movement against Maastricht Treaty also birthed new political parties. The Federation of Free Citizens (Bund für Bürger, BfB), formed in 1994 and inspired by the Liberal Party of Austria, is an example of such. The party was founded on pillars that consist of economic liberalism, heavy criticism of EU economic policy, and opposition to Eurocentrism, which would operate according to political consensus rather than the logic of the market and competition. Joachim Starbatty, former deputy leader of the $\mathrm{BfB}$, was a representative of opposition to the Euro system whose criticism was backed by Ordoliberalism. Franz-Ulrich Willeke, an economics professor at the University of Heidelberg, was also a deputy leader of the $\mathrm{BfB}$, and others such as Roland Vaubel and Willhelm Hankel, both economics professors, did not join the party but openly endorsed it. Karl Albrecht Schachtschneider, a jurist and a founding member of the BfB, was also a wellknown anti-Europeanist. He, along with Starbatty, Hankel, and others, filed a constitutional appeal against The Amsterdam Treaty, which can be regarded as a follow-up measure to the Maastricht Treaty. BfB members and supporters, who stood at the forefront of opposition against the Euro system, would eventually become the key members of the AfD.

Opposition to European Integration, which somewhat subsided after the introduction of the Euro, was re-ignited by the Euro Crisis in Germany (Handelsblatt 2012). Germany, which feared that the financial crisis of southern European countries could potentially lead to the collapse of the Eurozone and wreak economic havoc across Europe, agreed to establish the European Financial Stability Facility (EFSF) and provide funding for countries in crisis, including Greece. There was an outpouring of criticism of bailout and the Euro system from institutional political entities, especially the ruling party, the CDU/CSU, and even from the coalition partner, FDP. In April 2011, the Small and Medium-Sized Business Association of the CDU/CSU (Mittelstands- und Wirtschaftsvereinigung der CDU/CSU), one of the influential lower branches of the $\mathrm{CDU} / \mathrm{CSU}$, announced a resolution declaring its averse position on the establishment of the European Stability Mechanism (ESM) that was being discussed. The Liberal Awakening (Liberaler Aufbruch), which is a faction of the FDP with a marked tendency toward economic liberalism, gave harsh criticism of the excessive government intervention in the Euro Crisis. In May 2012, ten members of the Federal Parliament belonging to the CDU/CSU and the FDP jointly organized the Alliance Against the ESM (Allianz gegen den $E S M)$. Such movements of opposition, however, did not resonate well within the existing political party system.

On the other hand, movements against bailouts and the Euro system outside institutional politics were not negligible. Economic liberal economists and business leaders who were critical of European integration began to organize against European integration once more. The Ifo Institute for Economic Research, one of the largest economic research institutes in 
Germany with a representative Euro critic Hans-Werner Sinn as its director, released the Bogenberg Declaration in October 2011, and directed fundamental criticism at the Euro system for bringing about the Euro Crisis. Hans-Olaf Henkel, former IBM executive and president of the Federation of German Industries and of Leibniz Association, openly endorsed the Liberal Awakening of the FDP and the Free Voters (Freie Wähler), and played a pivotal role in connecting politics, business, and academia using his involvement with think tanks such as the Initiative New Social Market Economy, the Mont Pelerin Society, and the Hayek Society. One must not forget Lucke, who birthed the Alliance for Citizens' Will (Bündnis Bürgerwille) movement and later went on to become the first co-chair of AfD. After successfully organizing hundreds of like-minded economists through the announcement of the Hamburg Appeal (Hamburger Appell) in 2005 and the Plenum of Economists (Plenum der Ökonomen) in 2010, Lucke established the Alliance for Citizens' Will in 2011 and rallied not only scholars, politicians, and activists who opposed bailout but also the general public. In the following year, he led the organization of Electoral Alternatives 2013 (Wahlalternative 2013) with Alexander Gauland and Konrad Adam who were disappointed by the CDU's response to the Euro Crisis and defected from the party. Together, they attempted to place opposing bailout, abandonment of the single Euro, and freedom to withdraw from the Eurozone on the map as key agendas for a series of elections that were going to be held in 2013. Initially, the Electoral Alternatives 2013 started as a nonpartisan political group, and was meant to tackle the election in cooperation with the anti-Euro-oriented Free Voters. However, after witnessing the disappointing vote share $(1.1 \%)$ of the Free Voters in the Niedersachsen State Parliament election, which was exacerbated by his tensions with the party leader Hubert Aiwanger, Lucke switched strategy to form a political party. The AfD was the product of this decision (Bebnowski 2015: 19-31; Häusler and Roeser 2015: 65-78; Oppelland 2017).

In its early stage, the AfD was led by the economic liberal faction centered on Lucke. Lucke was a co-representative of the party, along with Adam and Petry, but in practice led the party on his own using his large vote share in the party representative election and publicity to legitimize his authority. Of the seven members of the AfD elected in the 2014 European Parliament election, five members identified themselves as part of the economic liberal faction - Lucke, Starbatty, and Henkel were all among them. It was only natural for their radical tendency to be translated into their policy. Furthermore, numerous economists who were involved in the party must have exerted a significant amount of influence on its economic policies. Economist Starbatty was the representative of the academic advisory committee of the party, and economist Vaubel, a member of the academic advisory committee under the German Ministry of Economics, was also part of the committee. According to Bebnowski and Förster (2014: 14-18), this economic liberal faction was strongly rooted in ordoliberalism. The ordoliberal standpoint recognizes the role of the state, but holds that it should only exist for the market and not against it, and that the dissolution of the Eurozone was a rightful measure that could free the market from the reigns of politics. Furthermore, ordoliberals believe that in order for the principle of competition to work smoothly, market results should be left entirely to the individuals, and all artificial attempts to correct this under the name of social justice ruled out. Since the AfD was based on such ideals, its economic policies were adjusted to accommodate basic trends such as market liberalism, laissez faire and minimal state intervention philosophies, and anti-interventionism. These principles take form in more specific 
policies such as passive labor market intervention, reduction of social insurance expenditure, tax rate reduction, and tax repeal. Where the ideals of another faction within the party came in contact with radical market ideology, as it will be discussed below, the agenda of the economic liberal faction was converted into policies without much hindrance.

\section{National Conservatism, anti-immigration, and anti-refugee agenda}

The final destination of the Eurosceptic economic liberalistic forces, which emerged in the opposition to the Maastricht Treaty at the beginning of 1990s and flourished during the Euro Crisis at the end of 2000s, was the AfD, but the party was not for themselves only. The national conservatives, who have been with the AfD since the Electoral Alternatives 2013 at the latest, took up a significant portion of the party membership (Bebnowski 2015; Häusler and Roeser 2015: 13-27; Werner 2015: 51-60). Gauland and Adam led the Electoral Alternatives 2013 with Lucke, but they were national conservatives and their ideologies differed from his. Petry is also classified as a national conservative. Even though she left the party shortly after the 2017 Federal Parliament election as a result of power and line struggles, she has served as the face of the AfD since Lucke. Beatrix von Storch, who is a member of the European Parliament, as well as co-deputy leader, is also worth mentioning. As the head of the Civil Coalition (Zivile Koalition) that claims to be the German version of the Tea Party, and has been cooperating with economic liberals since the Alliance for Citizens' Will, she still represents the retrospective, Christian conservatism in the party. Marcus Pretzell, a member of the European Parliament, and Björn Höcke of Thuringia are other symbolic figures of the far right and key forces in national conservatism.

Economic liberal forces and national conservative forces could coexist despite their differences, and this can be attributed to the political environment at the time of their union. First, the Euro Crisis and bailout provided a point of political contact for the two groups. Both of them fiercely opposed the existing form of European Integration and financially supporting countries in financial crisis. From the standpoint of Eurosceptic economic liberalism, bailout was deemed an uneconomical and irrational measure whose practical implication was outweighed by its cost, and regarded as a byproduct of political decisions against market logic. It was moreover seen as an invasion of private property by the state in that the bailout used taxpayers' money to support other countries. The European Integration that would violate national sovereignty and national identity is something difficult for national conservatives to accept. They also assured that bailout measures for Eurozone countries in crisis would never benefit Germany. Second, both forces shared the need for a new party. There was no political party that represented the Eurosceptic economic liberals among the existing political parties. The existing parties maintained essentially the same position with regard to bailout, since they did not deny the need for the Eurozone or financial support itself (Lees 2008; Wimmel 2012). Dissatisfaction with the existing party system was not new to the national conservatives. Some of them, such as Gauland, served as critics in the CDU. They feared the prospect of "socialdemocratization of the CDU" under Merkel and contended that the party should be more nationalistic, statist, Christian, and traditional. The organization Civil Coalition represented such trends outside 
institutional politics. Third, the economic liberal faction and national conservative faction had strategic need for each other. For the former, the latter could complement their insufficient popularity, while for the latter, the former could hide their radical tendency, lest they become labeled as right-wing extremists (Korsch 2014; Plehwe 2014; Häusler and Roeser 2015: 16-22). ${ }^{3}$

This is not to say that there existed no ideological point of contact between economic liberalism and national conservatism. As Bebnowski and Förster (2014: 19-24) correctly pointed out, the logic of economic competition, which underlies Eurosceptic economic liberalism, complements the national pride of national conservatives, embodied in the idea that Germany rose as the winner from market competition because it had superior economic capabilities. Economic liberals believe that Germany's economic success is rooted in the innate superiority of the Germans, that they were diligent and productive, unlike the citizens of the southern European countries that were suffering from crisis, and were pre-conditioned for linking economic superiority to cultural and national superiority. Hierarchical ranking based on superiority and social Darwinian struggle for survival underpin the perceptual basis of not only the harsh economic liberals but also rigorous national conservatives. Economic liberalism does not necessarily clash with what is culturally conservative in practice - Lucke is a good example of this. Although liberal-minded in regard to economics, he is a devout Protestant and stubbornly conservative on matters such as multiculturalism and homosexuality (Korsch 2014: 7-8; Bebnowski 2015: 19-22; 2016).

The AfD established itself as the anti-Euro party, groomed by the political climate of the Euro Crisis and bailout. However, it was not a single-issue party that paraded only an anti-Euro agenda. Although it did not emphasize these features as heavily in its early stage, the party was anti-immigration and anti-refugee from the beginning (Häusler 2015: 2-3). After joining with national conservative forces, it began to actively address the issue of immigration and refugees that economic liberals focused little on. Within the national conservative framework, an ethnic group sharing homogeneous, "German" traits living together as a nation-state is the most desirable. Such ideals stem from engrossment with national identity and national sovereignty. Family is considered to be a basic unit of society that reproduces traditional values and "German" characteristics. Europeanization driven by the $\mathrm{EU}$ is a threat against national identity and national sovereignty, and homosexuality and gender equality, which disrupt traditional family structure, are issues that the national conservatives of the AfD say they can never accept. This is coupled with their strong opposition to immigration and refugees. Outsiders who are not "German," especially the Muslims who are seen as unable to assimilate into the Christian culture that shapes the backbone of traditional German society, are sources of fear for national conservatives who want to maintain the German national identity and traditional image of family (Bebnowski 2015: 5-11). Petry's absurd statement during an interview with a local daily newspaper suggesting that firearms can be used in the case of emergency when unregistered refugees are attempting to illegally enter Germany (Mannheimer Morgen 2016), and parochial slogans with messages such as "not multi-culture but German culture centered (Deutsche Leitkultur)" (AfD 2016a: 47) and "Islam is not a part of Germany" (Ibid. 49), should come as little surprise when the basic doctrine of the party is rooted in such extreme exclusivity. 
Along with changes in circumstances within and outside the party, the AfD's anti-Euro platform has been gradually marginalized while their anti-immigration and anti-refugee agenda gains prominence. The national conservative faction's victory in the internal power and line struggle against the economic liberal faction brought about conclusive results. Conflicts between the two formerly dominant factions have been gradually surfacing following the 2014 State Parliament election. The encouraging election results in the former East Germany areas of Sachsen, Brandenburg, and Thuringia boosted Petry's stance within the party because she represents Sachsen and former East Germany, while also threatening Lucke, who once held overwhelming status in the party. The conflict between the two factions escalated further as far-right extremists were systematically flown in under the connivance of national conservatives from the former East Germany area and dominated the party. The outbreak of the conflict revealed differences in the positions of the two factions on right wing extremism, and added more fuel to the conflict. While the economic liberal faction was concerned about the far-right, radical, and xenophobic nature of the Patriotic Europeans Against the Islamization of the West (Patriotische Europäer gegen die Islamisierung des Abendlandes, PEGIDA) and wanted to distance themselves from it, the national conservative faction wanted to expand their support base in the former East Germany area and insisted on strengthening solidarity with PEGIDA. The tedious conflict ended when Lucke left the party with over 2000 economic liberals, including Starbatty and Henkel, immediately following his overwhelming defeat to Petry at the national convention held in Essen in July 2015. Even though the national conservative faction maintained the party's anti-Euro agenda, the party's shift toward an anti-immigration and anti-refugee agenda was inevitable (Häusler 2015).

From the outside, a series of immigration and refugee-related happenings lead to a change of social atmosphere, and further empowered the AfD's anti-immigration and anti-refugee agenda. German society, which was relatively generous to immigrants and refugees, even following the decision to accept Syrian refugees in August 2015, turned rapidly sour after a series of tragedies, including the terrors of November 2015 in Paris, Brussels in March 2016, Nice in July, the group sexual assault in Cologne in December 2015, the train axe terror in Würzburg in July 2016, the random shooting in Munich, the Ansbach bomb terror, the assault with deadly weapon in Reutlingen, and the truck attack in Berlin in December. When the other political parties were essentially not opposed to the Merkel government's open immigration and refugee policies, the AfD's obvious opposition had considerable appeal not only for voters who were already hostile to foreigners but also for ordinary voters who were concerned that the government's immigration and refugee policies might be "naive" (Hambauer and Mays 2017).

\section{Anti-immigration and anti-refugee sentiments as key motivators}

Rüdiger Schmitt-Beck (2014) published an interesting finding on the main supporters of the AfD in his study that analyzed the 2013 Federal Parliament election. The study showed that, although not completely exclusive from one another, the supporters of the AfD could be divided into two separate groups, with distinct motivations for support and times at which they decided to participate in the vote. The first group voted for the AfD from the beginning, considered the Euro Crisis to be the most important political issue, and was critical of the government's financial support for the European countries 
in crisis. The respondents belonging to this group were, unlike ordinary voters, pessimistic about the future of the domestic economy and generally dissatisfied with the existing administration, including its coping strategy with the Euro Crisis. They did not perceive immigration to be a particularly important issue. The second group decided to rally around the AfD closer to the voting day, and was drawn in by its clear anti-immigration policy more than anything else. These supporters were also influenced by the Euro Crisis, but unlike the other group, their decisions were primarily driven by abstract fear of immigrants and refugees, rather than concerns about the domestic economy. They were relatively less interested in politics per se and primarily resided in the former East Germany. Their hostility toward the government was usually aroused by their repulsion toward Chancellor Merkel rather than a calculated evaluation of state affairs. In short, the supporters of the AfD during the election period are divided into "early decision-makers" who sympathized with the party's anti-Euro agenda and "late decision-makers" who sympathized with its anti-immigration agenda. It is necessary to pay attention to the ratio of the two groups to the whole demands. According to Schmitt-Beck's analysis, the first group accounted for about $30 \%$ of the total supporters and the second group accounted for about $70 \%$. This ratio persisted at least until the 2014 European Parliament election (Schmitt-Beck 2017). Considering that the AfD in the early stage of its establishment was generally regarded as a singleissue party with an anti-Euro agenda, the results are rather surprising. Anti-immigration and anti-refugee policies attracted more supporters than anti-Euro policies did.

This is also shown in the analysis results of State Parliament election by Infratest dimap (2013-2017). Immigration and refugee issues played the most decisive roles in AfD's success across all elections after 2015, when relevant data existed. ${ }^{4}$ There are slight differences depending on the state, but those issues proved to be the most crucial when choosing a party for about $60 \%$ of the supporters (see Fig. 7), and the issues surrounding immigration and refugees contributed the most to the support for the AfD in all states. On the other hand, those who identified "economy and labor" as the most crucial issues made up only an average mid-20\% of the total supporters. This issues had less influence than "social justice" or "domestic security" in drawing supporters across all states except Mecklenburg-Vorpommern.

The AfD's supporters are motivated for quite different reasons than those of the supporters of other parties. In Berlin respondents who identified "economy/labor" as

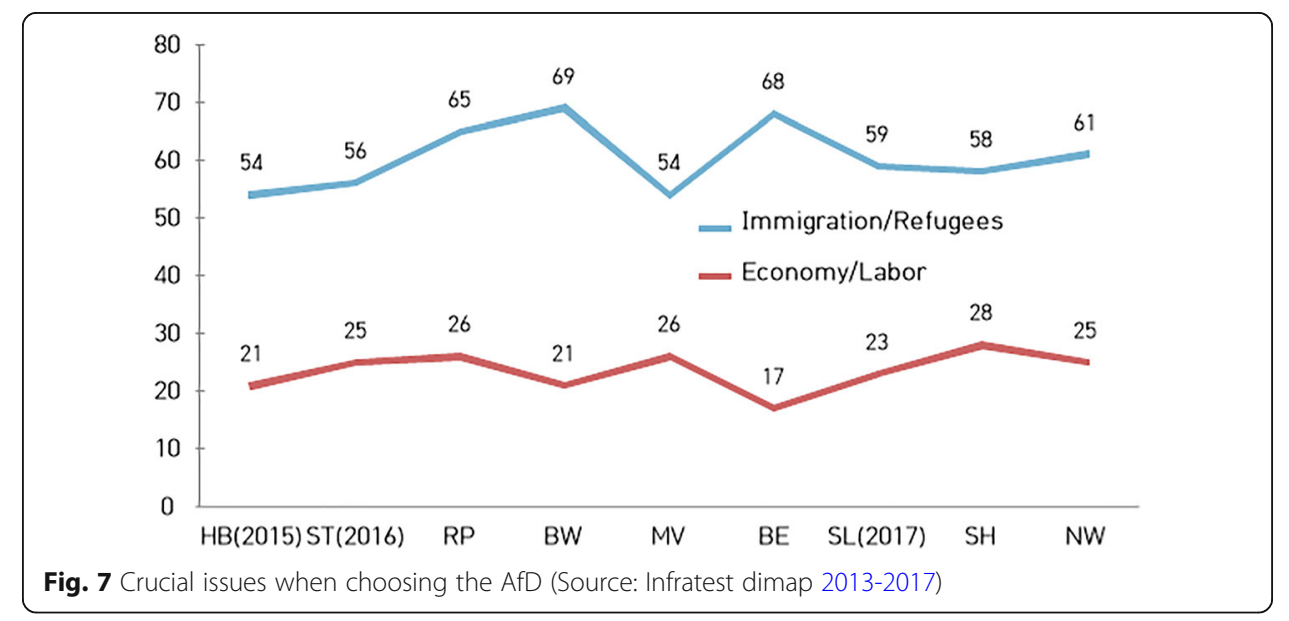


the crucial motives were placed first at 53\% for the CDU, 36\%(2) for the SPD, 56\%(1) for the FDP, and 28\%(3) for the Left Party. "Immigration/refugees" did not even place fourth as the factor that determined the voters' decisions. ${ }^{5}$ The results were not much different in North Rhine-Westphalia, where one of the latest State Parliaments elections was held. "Economy/labor" marked 50\%(1) for the CDU, 38\%(2) for the SPD, 50\%(1) for the FDP, 20\%(4) for the Greens, and 29\%(3) for the Left Party, and "immigration/refugees" placed below fourth place for all parties. In Berlin and North Rhine-Westphalia and all of the other states, the results were diametrically different from that of the AfD, for which "immigration/refugees" served as the most influential factor (Infratest dimap 2013-2017).

The fact that many of the supporters were moved to vote for the AfD by its anti-immigration and anti-refugee stance can also be observed indirectly through the changes in the party's approval rating. As shown in Fig. 8, the polls in support of the AfD was less than $5 \%$ after the establishment of the party and increased to $6-8 \%$ as a result of the State Parliament election, but dropped again to less than $5 \%$ with the rise of internal conflicts and the division of the party. The approval rating for the AfD saw an explosive increase, however, as the problem of immigration and refugee issues become more pronounced following the influx of refugees to Germany since September 2015, the Cologne incident in December 2015, and the Brussels terror in 2016.

Blue collar workers and the unemployed responded most sensitively to immigration and refugee issues and contributed to the sharp increase in AfD's polls. As stated above, the approval rating of the AfD from blue collar workers and the unemployed increased dramatically after the 2016 State Parliament elections, which coincides with the exact period when issues of immigration and refugee were raised. The approval rating for the AfD among blue collar workers in State Parliament elections held in Hamburg and Bremen in the first half of 2015 were only $11 \%$ and $7 \%$, respectively, but in the State Parliament elections held in Sachsen-Anhalt, Rhineland-Palatinate, and Baden-Württemberg the values reached 35\%, 23\%, and 30\%, respectively (Infratest dimap 2013-2017). This pattern was the same for unemployed voters as well. The approval rating

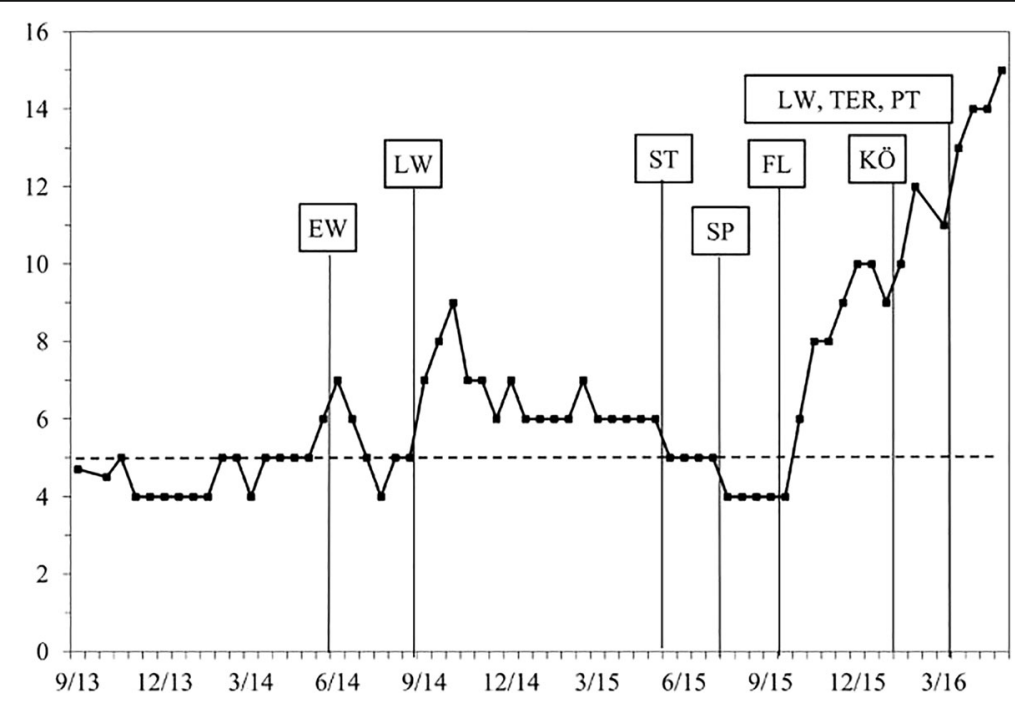

Fig. 8 Changes in approval rating for the AfD (Niedermayer and Hofrichter 2016: 268) 
in two elections of 2015 was 7\%, but it sharply increased to 36\%, 25\%, and 32\%, respectively in the 2016 elections (Ibid.). In a short period of about one year, the AfD obtained 3.3 times and 4.4 times higher approval rating from blue collar workers and the unemployed, respectively. Given the social climate at the time, this provides a compelling reason to think that immigration and refugee issues played a decisive role in the spike. Of course, blue collar workers and the unemployed were not the only ones who grew more supportive of the AfD. There is no other social group, however, that responds as sensitively and consistently as these groups. Figure 9 shows the overall approval rating and differences in approval rating across type of employment for a total of 10 elections held between 2014 and 2016. The approval ratings of blue collar workers and the unemployed were higher than the overall approval rating, and show a sharp increase since 2016. These values stand in sharp contrast to other groups, in which they have lower than overall average approval rating and smaller range of changes.

By placing strong emphasis on anti-immigration and anti-refugee policies, the AfD was able to make blue collar workers and the unemployed, who would benefit the least by its radical market-oriented policies, into their most active support groups. This feat was possible due to the AfD's election strategy, which hid its market radical nature and provocatively highlighted immigration and refugee issues. Upon analysis of Federal Parliament election manifestos and press releases that AfD published throughout 2013, Franzmann (2014: 121-123) identified a gap between the party's policies and its actual support mobilization methods. According to Franzmann, the AfD's right-wing populist agenda was not indicated in its election pledge, but was gradually made more visible as the election campaign progressed. This shift is also pointed identified in Schmitt-Beck's study (2014: 110-112), which finds that the AfD emerged as an anti-Euro party, then gradually assumed the language of right-wing populists. Negativity toward immigration was expressed more frequently over time, and by doing so, the party was able to attract voters who sympathized with anti-immigration policies in large number toward the end of the election.

The AfD's discreet strategy for the 2017 Federal Parliament election that leaked in 2016 confirmed that Franzmann and Schmitt-Beck's observations were not coincidental but results of sophisticated strategy (AfD 2016b). The leaders were fully aware that the party is supported by heterogeneous social groups, and that the reasons for their support were unrelated to the party's ability to resolve given issues, but rather because it has

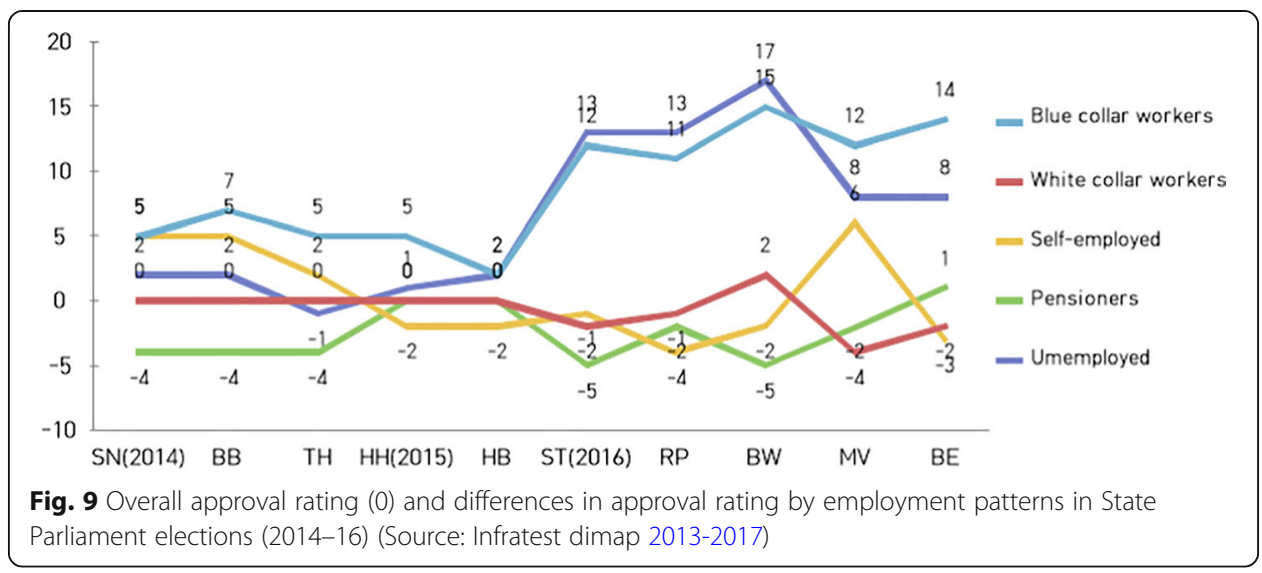


advocated anti-Euro, anti-immigration, and anti-refugee sentiments, which have been made taboo in the existing political circles. Furthermore, they recognized that economic and social policies have not improved their chance in elections despite their importance, but could potentially divide heterogeneous supporters.

The top priority is to carry out the election campaign in 2017 with issues that do not bring about internal division among the supporters of the AfD. The issues (especially economic and social policies) that have been not required in order to ensure the AfD's success in the elections so far should be handled with utmost care to prevent division of the party's supporting base. Liberal-conservative citizens and blue collar workers and the unemployed can share similar positions for issues such as Euro/Europe, security, immigration/Islam, democracy, national identity or genderism, but could have differing views in areas such as tax justice, pension entitlements, medical insurance premiums, restrictions on rent increase or unemployment insurance. (AfD 2016b: 8)

Therefore, the AfD's election strategy was, on the one hand, to highlight issues that all supporters could agree on, using "meticulously planned provocation" (Ibid. 11), while downplaying sensitive issues that could divide its support base using strategic ambiguity and intentional concealment. It was only natural that the general voters are left only with the image of the AfD as champions of anti-immigration and anti-refugee policies while the image of determined free-market advocates fades into the background. The AfD was able to adhere to market radical economic policies and simultaneously retain the support of social groups who would be detrimentally affected by those very policies. Not only do economic issues pique less interest for groups such as the blue collar workers and the unemployed; they are also more difficult to comprehensively present to voters.

\section{Conclusions}

Amidst the Euro Crisis and international bailout, the AfD distinguished itself from the existing political parties and established itself as a key player in institutional politics faster than any other party in German history. It missed its chance at entering the Federal Parliament in 2013 by a close margin, but its seven members were elected for European Parliament the following year, and subsequently accomplished the feat of having its members elected for the Parliament in all states where elections were held. As a result, The AfD is participating in 14 out of 16 Parliaments of the Federal Republic of Germany, and secured its position as the main opposition party in Sachsen-Anhalt and MecklenburgVorpommern. In addition, the party has made remarkable accomplishments and realized its long-held desire of advancing into Federal Parliament, and positioned itself as a major political party in Germany. Even though only five years have passed since its establishment, the AfD boasts a considerable presence in Germany's institutional politics.

Its success was made possible due to rapturous support from blue collar workers and the unemployed. They played a crucial role in this success, although not from the beginning. In the early period of the AfD, its constituency was characterized rather by well-educated, high-income groups, which were quite in contrast to the blue collar workers and the unemployed. However, the latter's numbers grew rapidly in relation to the overall demographics of the party's supporters and took on increasing importance. 
The blue collar workers and the unemployed were not alone in supporting the AfD, but the intensity of their support was unparalleled by other social groups that also supported the party. Surprisingly, the AfD's economic policies are not friendly to blue collar workers and the unemployed, and are in fact based on a radical market ideology that could harm them. The party is averse toward the minimum wage system and has not prepared policies to address it. Its social insurance policies are based on a merit system restrictive enough to bring shame to the fundamental purpose of the social insurance. The tax policy, whose main point is to weaken the progressive nature and abolition of some taxes, is designed to bring adverse effects to income redistribution.

This paper analyzed the contradictory phenomenon behind the success of the AfD, namely the discrepancy between the party's support group and its policy direction, in relation to the party's formation and development, and forces within the party and their major agendas. The party's radical market-oriented economic policies can be understood when one examines the forces of economic liberalism that played a leading role in the early days of its formation. The Eurosceptic economic liberals who emerged in response to the "anti-market" Maastricht Treaty of the early 1990s gathered to form the AfD after the Euro Crisis, and their radical ideologies were reflected in their economic policy. In the early days when the party established itself as anti-Euro party, it was relatively less prominent, but it also harbored anti-immigrant and anti-refugee agenda. For the economic liberal forces, immigration and refugee issues were less important than the Euro. However, as the national conservative forces joined the party and overpowered the previously dominant economic liberal faction, the issue of immigration and refugees was emphasized and the party's already anti-immigration tendencies began to strengthen.

Interestingly, it was found that much of the support for the AfD was backed by anti-immigrant and anti-refugee sentiments, not the party's anti-Euro stance. It is the blue collar workers and the unemployed who have been particularly aroused by the immigration and refugee policies proposed by the AfD. As its anti-immigration and anti-refugee agenda grew more pronounced following the victory of the national conservatives in the power struggle within the party, coupled with the refugee crisis and other immigrant/refugee-related incidents, the approval rate from the blue collar workers and the unemployed rose faster than that of any other social group. The blue collar workers and the unemployed became the core groups supporting the party, while its radical market-oriented policies remained unchanged. It is here that we can explain the discrepancies between the party's support groups and the party's policy agenda. Although its economic policies contradict the interests of the blue collar workers and the unemployed, the AfD was able to gather much support from these social groups thanks to its hardline anti-immigration and anti-refugee rhetoric. It was difficult for these groups to recognize the self-deceptive nature of supporting the AfD, owing to the party's shrewd strategy that hid its radical market-based agenda while highlighting immigration and refugee problems.

It is unclear whether the AfD will maintain its economic stance, now that the economic liberal faction has left the party - this stance does not seem helpful in strengthening its support base, and in fact might jeopardize its poll ratings. Given that populist parties often switch their positions according to the political climate, it would not be surprising if the AfD suddenly changed its position. In other words, the discrepancies between the party's support group and its policy direction could be 
temporary. The AfD may abandon its radical market-oriented policies if these lead to a decline in support from blue collar workers and the unemployed. It is moreover not difficult for the AfD to change its economic stance fundamentally due to the absence of the economic liberal faction within the party. The French National Front, one of the most successful political parties in Europe now, also opposed economic intervention of the state and advocated for anti-taxation, but came to represent the interests of blue collar workers and vulnerable minorities when its polling rate was in question. Will the AfD follow the path of the French National Front, or retain its model of economic liberalism like the Freedom Party of Austria? The answer lies in the aftermath of the federal parliamentary election.

\section{Endnotes}

${ }^{1}$ When AfD supporters for the first quarter of 2016 were classified by their livelihood activities, the proportions were as follows: employed 63\%, unemployed 3\%, pensioner $27 \%$, and others $7 \%$. When employed supporters were classified by their occupation, the proportions were: blue collar workers $26 \%$, white collar workers $53 \%$, government employees 7\%, and self-employed 14\% (Niedermayer and Hofrichter 2016: 272).

${ }^{2}$ The party's stance on the fiscal equalization among the federal states (Länderfinanzausgleich) is also worth exploring. The AfD demands that each state be financially independent without receiving assistance from the federal government or other states. AfD has a higher approval rating in the former East Germany where the economy is relatively underdeveloped compared to its western counterpart, so this policy can only be understood as a manifestation of the AfD's ideological beliefs (AfD 2016: 76).

${ }^{3}$ The $\mathrm{BfB}$ and the $\mathrm{AfD}$ overlapped not only in their ideologies but also in their personnel. This explains why the BfB, which disappeared in 2000 and failed to make a splash in German politics, was able to draw attention (Bebnowski and Förster 2014: 9-11; Häusler and Roeser 2015: 28-32; Werner 2015: 19-33).

${ }^{4}$ In the questionnaire, the questions vary slightly for each election, but almost all are directed at determining the most crucial determinant issue in choosing a political party (multiple answers are allowed). Relevant questions were asked in 2015 State Parliament election in Hamburg, but in the case of the AfD, since the items related to "economy/ labor" were not within the ranking, they were not reflected on Fig. 7. Response items are also different for each election. Items related to "immigration/refugees" include the words "immigration," "refugees," or "foreigners," and items related to "economy/labor" usually include the phrase "economy and labor" (Infratest dimap 2013-2017).

${ }^{5}$ The Greens recorded 20\%(4) for "immigration/refugees" and "economy/labor" was pushed out of the ranking. Considering the motivations recorded for supporters for the Greens in other states, these results are not usual (Ibid.).

Abbreviations

AfD: Alternative for Germany (Alternative für Deutschland); BfB: Federation of Free Citizens (Bund für Bürger); CDU: Christian Democratic Union (Christlich Demokratische Union Deutschlands); CSU: Christian Social Union (Christlich-Soziale Union in Bayern); FDP: Free Democratic Party (Freie Demokratische Partei); PEGIDA: Patriotic Europeans Against the Islamization of the West (Patriotische Europäer gegen die Islamisierung des Abendlandes); SPD: Social Democratic Party of Germany (Sozialdemokratische Partei Deutschlands) 
Authors' contributions

The author read and approved the final manuscript.

\section{Authors' information}

Juho Kim got his PhD from Goethe University Frankfurt in Germany and is currently working as research colleague of the DAAD-Center for German and European Studies (ZeDES) at Chung-Ang University in South Korea. His main research areas are political sociology, sociological theory, democracy and populism, and European studies.

\section{Competing interests}

The author declares that he has no competing interests.

\section{Publisher's Note}

Springer Nature remains neutral with regard to jurisdictional claims in published maps and institutional affiliations.

Received: 19 February 2018 Accepted: 29 April 2018

Published online: 21 May 2018

\section{References}

AfD. 2013. Wahlprogramm. http://www.afd-hessen.org/wp-content/uploads/2013/07/Wahlprogramm-AFD.pdf. Accessed 20 Dec 2017

AfD. 2016a. Programm für Deutschland - Das Grundsatzprogramm der Alternative für Deutschland. Berlin: AfD.

AfD. 2016b. AfD-Manifest 2017 - Die Strategie der AfD für das Wahljahr 2017. http://rettetdiewahlen.eu/wp-content/ uploads/2017/02/338294054-AfD-Strategie-2017.pdf. Accessed 20 Dec 2017.

AfD. 2017. Programm für Deutschland - Wahlprogramm der Alternative für Deutschland für die Wahl zum Deutschen Bundestag am 24. September 2017. Berlin: AfD.

Bebnowski, David. 2015. Die Alternative für Deutschland - Aufstieg und gesellschaftliche Repräsentanz einer rechten populistischen Partei. Wiesbaden: Springer VS.

Bebnowski, David. 2016. "Gute" Liberale gegen böse Rechte? - Zum Wettbewerbspopulismus der AfD als Brücke zwischen Wirtschaftsliberalismus und Rechtspopulismus und dem Umgang mit der Partei. In Die Alternative für Deutschland Programmatik, Entwicklung und politische Verortung, ed. Alexander Häusler, 25-35. Wiesbaden: Springer VS.

Bebnowski, David, and Lisa Julika Förster. 2014. Wettbewerbspopulismus - Die Alternative für Deutschland und die Rolle der Ökonomen. Frankfurt am Main: Otto-Brenner-Stiftung.

Bergmann, Kurt, Matthias Diermeier, and Judith Niehues. 2016. Die AfD - eine Partei der Besserverdiener? https://www iwkoeln.de/fileadmin/publikationen/2016/280617/IW-Kurzbericht_2016-19-AfD.pdf. Accessed 11 Dec 2017.

Brähler, Elmar, and Oliver Decker. 2014. Die Parteien und das Wählerherz 2014. http://home.uni-leipzig.de/decker/ waehlerherz_2014_grafiken.pdf. Accessed 13 Dec 2017.

Brähler, Elmar, Johannes Kiess, and Oliver Decker. 2016. Politische Einstellung und Parteipräferenz - Die WählerInnen, Unentschiedene und Nichtwähler 2016. In Die enthemmte Mitte - Autoritäre und rechtsextreme Einstellung in Deutschland, ed. Elmar Brähler, Johannes Kiess, and Oliver Decker, 67-94. Gießen: Psychosozial-Verlag.

Frankfurter Allgemeine Zeitung. 2014. AfD-Chef: Der Mindestlohn schadet Deutschland. http://www.faz.net/aktuell/ wirtschaft/wirtschaftspolitik/afd-chef-lucke-der-mindestlohn-schadet-deutschland-12887785.html. Accessed 23 Dec 2017 .

Franzmann, Simon Tobias. 2014. Die Wahlprogrammatik der AfD in vergleichender Perspektive. Mitteilung des Institutes für Internationales Parteienrcht und Parteienforschung 20: 115-124.

Hambauer, Verena, and Anja Mays. 2017. Wer wählt die AfD? - Ein Vergleich der Sozialstruktur, politischen Einstellungen und Einstellungen zu Flüchtlingen zwischen AfD-Wählerlnnen und der WählerInnen der anderen Parteien. Zeitschrift für Vergleichende Politikwissenschaft. https://doi.org/10.1007/s12286-017-0369-2. Accessed 7 Jan 2018.

Handelsblatt. 2012. Wutbürger sammeln sich zum Euro-Angriff. http://www.handelsblatt.com/politik/international/allianzgegen-merkels-rettungsschirm-politik-wutbuerger-sammeln-sich-zum-euro-angriff/6684206.htm. Accessed 5 Jan 2018

Häusler, Alexander. 2015. Die AfD - Partei des rechten Wutbürgertums am Scheideweg. http://library.fes.de/pdf-files/ dialog/11390-20150911.pdf. Accessed 5 Jan 2018.

Häusler, Alexander, and Rainer Roeser. 2015. "Mut"-Bürger - Entstehung, Entwicklung, Personal \& Positionen der Alternative für Deutschland. Hamburg: VSA.

Infratest dimap. 2013. Bundestagswahl 2013. http://wahl.tagesschau.de/wahlen/2013-09-22-BT-DE/index.shtml. Accessed 5 Dec 2017

Infratest dimap. 2013-2017. Landtagswahlen und Bundesrat. https://wahl.tagesschau.de/landtag.shtml. Accessed 5 Dec 2017.

Infratest dimap. 2015. AfD rückt nach rechts, CDU nach links. https://www.infratest-dimap.de/uploads/media/ LinksRechts Nov2015 01.pdf. Accessed 20 Dec 2017

Infratest dimap. 2017. Bundestagswahl 2017. http://wahl.tagesschau.de/wahlen/2017-09-24-BT-DE/index.shtml. Accessed 5 Dec 2017.

Judith, John B. 2016. The populist explosion - How the great recession transformed American and European politics. New York: Columbia Global Reports.

Korsch, Felix. 2014. Nationalkonservativ und Marktradikal - Eine politische Einordnung der "Alternative für Deutschland.". Berlin: Rosa-Luxemburg-Stiftung.

Kösters, Wim, Mafred M. Neumann, Renate Ohr, and Roland Vaubel. 1998. Der Euro kommt zu früh. In Frankfurter Allgemeine Zeitung 9 February 1998

Lees, Charles. 2008. The limits of party-based Euroscepticism in Germany. In Opposing Europe? - The comparative party politics of Euroscepticism, ed. Aleks Szczerbiak and Paul Taggart, 16-37. Oxford: Oxford University Press.

Mannheimer Morgen. 2016. Sie können es nicht lassen! https:/www.morgenweb.de/mannheimer-morgen_artikel,-politiksie-koennen-es-nicht-lassen-_arid,751556.html. Accessed 6 Jan 2018. 
Niedermayer, Oskar, and Jürgen Hofrichter. 2016. Die Wählerschaft der AfD - Wer ist sie, woher kommt sie und wie weit rechts steht sie? Zeitschrift für Parlamentsfragen 47: 267-284.

Nocun, Katharina. 2016. Wie sozial ist die AfD wirklich? - Eine Expertise zu Positionen in der AfD bei der Sozial- und Steuerpolitik. Dresden: Heinrich-Böll-Stiftung Sachsen.

Ohr, Renate, and Wolf Schäfer. 1992. Die Währungspolitischen Beschlüsse von Maastricht - Eine Gefahr für Europa. Frankfurter Allgemeine Zeitung 11 June 1992.

Oppelland, Torsten. 2017. Alternative für Deutschland. https://www.bpb.de/politik/grundfragen/parteien-indeutschland/211108/afd. Accessed 5 Dec 2017.

Plehwe, Dieter. 2014. Durchmarsch der nationalen Neoliberalen? - Die AfD und die neue europäische Rechte. Blätter für deutsche und internationale Politik 2: 63-72.

Plehwe, Dieter. 2016. Alternative für Deutschland? Europäische und transatlantische Dimensionen des neuen Rechtsliberalismus. In Die Alternative für Deutschland - Programmatik, Entwicklung und politische Verortung, ed. Alexander Häusler, 53-66. Wiesbaden: Springer VS.

Priester, Karin. 2016. Rechtspopulismus - Ein umstrittenes theoretisches und politisches Phänomen. In Handbuch Rechtsextremismus, ed. Fabian Virchow, Martin Langebach, and Alexander Häusler, 533-560. Wiesbaden: Springer VS.

Schmitt-Beck, Rüdiger. 2014. Euro-Kritik, Wirtschaftspessimismus und Einwanderungsskepsis - Hintergründe des Beinah-Wahlerfolges der Alternative für Deutschland (AfD) bei der Bundestagswahl 2013. Zeitschrift für Parlamentsfragen 45: 94-112.

Schmitt-Beck, Rüdiger. 2017. The 'alternative für Deutschland in the electorate' - Between single-issue and right-wing populist party. German Politics 26 (1): 124-148.

Spiegel Online. 2016. So unsozial ist die AfD. http://www.spiegel.de/wirtschaft/soziales/afd-wirtschaftsprogrammstreichen-kuerzen-abschaffen-a-1082252.html. Accessed 20 Dec 2017.

Werner, Alban. 2015. Was ist, was will, wie wirkt die AfD? Karlsruhe: ISP.

Wimmel, Andreas. 2012. Deutsche Parteien in der Euro-Krise - Das Ende des Konsensprinzip? Integration 35 (1): 19-34

Submit your manuscript to a SpringerOpen ${ }^{\oplus}$ journal and benefit from:

- Convenient online submission

- Rigorous peer review

Open access: articles freely available online

High visibility within the field

Retaining the copyright to your article

Submit your next manuscript at $>$ springeropen.com 